Poblete, Y., G. E. Soto, L. Campagna, M. Ávila, C. Fernández, C. R. Flores, and A. D. Rodewald. 2020. Deforestation patterns shape population structure of the Magellanic Woodpecker (Campephilus magellanicus) in southern Chile. Avian Conservation and Ecology 15(2):19. https://doi. org/10.5751/ACE-01692-150219

Copyright (C 2020 by the author(s). Published here under license by the Resilience Alliance.

Research Paper

\title{
Deforestation patterns shape population structure of the Magellanic Woodpecker (Campephilus magellanicus) in southern Chile
}

\author{
Yanina Poblete $^{1}$ (D), Gerardo E. Soto ${ }^{2}$, Leonardo Campagna ${ }^{3}$, Miguel E. Ávila ${ }^{1}$, Carolina Fernández ${ }^{4}$, Cristian R. Flores $^{5}$ \\ and Amanda D. Rodewald ${ }^{2}$ \\ ${ }^{1}$ Núcleo de Investigaciones Aplicadas en Ciencias Veterinarias y Agronómicas (NIAVA), Instituto de Ciencias Naturales, Facultad \\ de Medicina Veterinaria y Agronomía, Universidad de Las Américas, Santiago, Chile, ${ }^{2}$ Cornell Lab Ornithology and Department \\ of Natural Resources and the Environment, Cornell University, Ithaca, New York, USA, ${ }^{3}$ Cornell Lab Ornithology and \\ Department of Ecology and Evolutionary Biology, Cornell University, Ithaca, New York, USA, ${ }^{4}$ Programa de Magister en Áreas \\ Silvestres y Conservación de la Naturaleza, Facultad de Ciencias Forestales y Conservación de la Naturaleza, Universidad de \\ Chile, Santiago, Chile, ${ }^{5}$ Escuela de Ingeniería en Gestión de Expediciones y Ecoturismo, Facultad de Economía y Negocios, \\ Universidad San Sebastián, Santiago, Chile
}

\begin{abstract}
One important landscape-scale consequence of deforestation is reduced connectivity, which has the potential to isolate populations in ways that affect genetic diversity and population structure. Among the many regions of the world where this scenario has played out is the South American temperate forest (SATF) in southern Chile, and there is now strong concern about the population viability of forest taxa. We studied one such species, the Magellanic Woodpecker (Campephilus magellanicus), a forest specialist that is now listed as vulnerable in parts of its range in Chile. We characterized genetic variability and population structure from 33 samples of Magellanic Woodpeckers from two large but isolated populations in Nahuelbuta National Park in the Coastal mountain range and the Conguillío National Park in the Andes using ddRAD-seq method. We found lower genetic variability in Nahuelbuta than Conguillío, but inbreeding values (FIS) did not show evidence for inbreeding depression. Results suggest the presence of two genetic clusters, with an average FST value of 0.04. Phylogenetic analysis showed that the Nahuelbuta population forms a clade that is nested within the individuals from Conguillío, suggesting limited gene flow between these populations. Our results support the idea that extensive deforestation has played a role in shaping the genetic patterns that we have identified. Because of this, we emphasize the need for regional planning to increase the structural connectivity between fragments of mature native forests, to provide an opportunity for the persistence of Magellanic Woodpeckers in this region.
\end{abstract}

\section{Les modèles de déforestation façonnent la structure de la population du Pic de Magellan (Campephilus magellanicus) dans le sud du Chili}

RÉSUMÉ. Une conséquence importante de la déforestation à l'échelle du paysage est la diminution de la connectivité, qui peut à son tour entraîner l'isolement des populations jusqu'à affecter leur diversité génétique et leur structure. La Forêt tempérée d'Amérique du Sud dans le sud du Chili figure parmi les nombreuses régions du monde où ce scénario s'est produit, et on s'inquiète désormais fortement de la viabilité des populations des taxons forestiers qui s'y trouvent. Nous avons étudié une de ces espèces, le Pic de Magellan (Campephilus magellanicus), spécialiste des forêts maintenant classé comme vulnérable dans certaines parties de son aire de répartition au Chili. Nous avons caractérisé la variabilité génétique et la structure de la population à partir de 33 échantillons de Pics de Magellan provenant de deux populations importantes mais isolées, dans le parc national de Nahuelbuta dans la chaîne de montagnes côtières et dans le parc national de Conguillío dans les Andes au moyen de la méthode ddRAD-seq. Nous avons trouvé une variabilité génétique plus faible à Nahuelbuta qu'à Conguillío, mais les valeurs de consanguinité (FIS) n'ont pas montré de signes de dépression de la consanguinité. Nos résultats indiquent la présence de deux groupes génétiques et une valeur FIS moyenne de 0,04. L'analyse phylogénétique a révélé que la population de Nahuelbuta forme un clade imbriqué dans les individus de Conguillío, laissant entendre qu'il existe un flux génétique limité entre ces populations. Nos résultats corroborent l'idée voulant que la déforestation extensive a joué un rôle dans la formation des modèles génétiques que nous avons identifiés. Nous croyons donc qu'il est nécessaire de planifier régionalement pour accroître la connectivité structurelle entre les fragments de forêts indigènes matures, afin d'assurer la pérennité du Pic de Magellan dans cette région.

Key Words: conservation; genetic variability; Magellanic Woodpecker; population structure; southern Chile.

Address of Correspondent: Yanina Poblete, Instituto de Ciencias Naturales, Universidad de Las Américas, Avenida Manuel Montt 948, Providencia, Santiago-Chile 750097, yanina.poblete@udla.cl 


\section{INTRODUCTION}

Landscape composition and configuration can profoundly affect genetic variability (DiLeo and Wagner 2016), with serious implications for persistence, ability to adapt to changing environments, and ultimately evolutionary potential of wild populations (Fisher 1958). When populations are sufficiently large and connected, high levels of gene flow promote high genetic variability and homogenization (England et al. 2003). However, in fragmented landscapes, populations can become isolated and genetic variability may decline to the point of increasing risk of local extinction (Lande 1994, Frankham 1995, Frankham et al. 2017a) and/or promoting differentiation and the emergence of new lineages (Wright 1978). The negative consequences of isolation seem most acute for forest ecosystems, possibly because most of the species that inhabit forests are not be able to cross deforested areas (e.g., Turner and Corlett 1996, Dale 2001, Foley et al. 2005, Bruggeman et al. 2010, Frankham et al. 2017b, BoteroDelgadillo et al. 2020). Therefore, information about genetic variability of forest-associated species may be crucial to identify meaningful biological units (e.g., subspecies), estimate population viability, and ultimately, to develop conservation strategies (Walters 1991, Allendorf and Luikart 2007, Palsbøll et al. 2007).

Within forest ecosystems, woodpeckers are known to be especially vulnerable to deforestation and forest degradation because of their high degree of specialization on old growth trees, which they use both to search for food and to build their nests (Lammertink 2014). Research shows that the global species richness of woodpeckers is strongly linked with tree cover, precipitation (Ilsøe et al. 2017), and presence of deadwood at the early decay stage (Tremblay et al. 2009); therefore, events that modify these conditions, such as climate change and human activities, have a strong impact on the woodpeckers' persistence (Billerman et al. 2016). Important examples of this are the cases of the two largest Campephilus species, the Ivory-billed Woodpecker (C. principalis Linnaeus 1758) and the Imperial Woodpecker (C. imperialis Gould 1832), both old-forest specialists driven to extinction as a result of habitat loss (Lammertink and Estrada 1995, Fitzpatrick et al. 2006). Likewise, research on other woodpeckers shows that habitat loss and fragmentation reduced genetic diversity, increased inbreeding, and lowered effective population sizes, e.g., Red-cockaded Woodpecker (Picoides borealis; Reed et al. 1988, 1993, Stangel et al. 1992, Haig et al. 1993, 1996, Blackwell et al. 1995, Schiegg et al. 2006, Bruggeman et al. 2010), White-backed Woodpecker (Dendrocopos leucotos; Ellegren et al. 1999), and Wryneck (Jynx torquilla; Mermod et al. 2009; Assandri et al. 2018).

The Magellanic Woodpecker (Campephilus magellanicus), the largest extant member of Campephilus $(40 \mathrm{~cm}, 276-363 \mathrm{~g}$; Short 1982) is an endemic and resident species of the South American temperate forests (SATF; Vuilleumier 1985). As a forest specialist, the Magellanic Woodpecker excavates mature and decayed trees both to forage for saproxylic insect larvae (Soto et al. 2017) and to build cavities for nesting and refuge (Ojeda 2004). Although this species is the largest of the four primary excavators of the SATF (Colaptes pitius, Veniliornis lignarius, and Pygarrhychas albogularis) that help support a diverse community of secondary cavity nesters (Altamirano et al. 2017), it might also serve as a potential seed disperser for non-Nothofagaceae trees in the Valdivian ecoregion (Soto et al. 2018). For these reasons, the
Magellanic Woodpecker has been proposed as a keystone and indicator species for the SATF (Ojeda and Chazarreta 2014) and also a charismatic species because of its great social-cultural value (Arango et al. 2007).

Unfortunately, a century of landscape change and deforestation have threatened the viability of Magellanic Woodpecker populations, thus prompting interest in its ecology (Ojeda 2004, Ojeda and Chazarreta 2006, 2014, Soto et al. 2016, 2017, 2018, Vergara et al. 2017, 2019). In addition to shrinking distribution due to deforestation (Ojeda and Chazarreta 2014, Vergara et al. 2017), populations suffer low reproductive output (Chazarreta et al. 2012), intraspecific competition (Soto et al. 2016), and harm from invasive species (Jiménez et al. 2014). Presently, the species is listed as endangered and vulnerable on the northern and southern extents of its distribution in Chile, respectively (Servicio Agrícola y Ganadero 2015). In this context, a better understanding of the genetic diversity and population structure of the Magellanic Woodpecker is crucial to develop conservation plans aimed to maintain genetic variation, particularly in small and/or isolated populations, and also to prevent the fixation of deleterious alleles with potentially negative fitness consequences (Van Dyke 2008).

The most isolated population of Magellanic Woodpeckers ( $>100$ $\mathrm{km}$ apart from other local populations) is located in the northern extent of their distribution, within the boundaries of the Nahuelbuta National Park (hereafter Nahuelbuta; 6832 ha; $37^{\circ}$ $49^{\prime} 03^{\prime \prime} \mathrm{S}, 73^{\circ} 02^{\prime} 03^{\prime \prime} \mathrm{W}$; Vergara et al. 2017). This population is located within the northern extent of the Valdivian rainforest ecoregion, one of the world's 32 biodiversity hotspots (Myers et al. 2007). This hotspot has been highly threatened by historic deforestation in the last centuries on the lowlands and low-slope hills, leading to a discontinuity of the forest between the two mountain ranges dominating the south-central part of Chile (Fig.1; Olson et al. 2001, Otero 2006). Consequently, Nahuelbuta is now an island of relatively continuous old-growth forest within a heavily fragmented region in the Nahuelbuta mountain range; extensive stretches of unsuitable habitat separate Nahuelbuta from mature forests in the Andes (Fig.1; Dinerstein et al. 1995, Cox and Kesley 2012).

The closest known potential nesting habitat for Magellanic Woodpecker to Nahuelbuta is located in high slope forests in the proximity of the Malleco National Reserve ( $38^{\circ} 08^{\prime} 03^{\prime \prime} \mathrm{S}, 71^{\circ} 47^{\prime}$ $\left.05^{\prime \prime} \mathrm{W}\right)$, about $100 \mathrm{~km}$ to the east on the Andes mountain range. However, the closest relatively large local population inhabiting low-slope mature forests can be found $\sim 50 \mathrm{~km}$ south from Malleco National Reserve, within the boundaries of the Conguillío National Park (hereafter Conguillío; 4500 ha; $38^{\circ} 38^{\prime} 39^{\prime \prime} \mathrm{S}, 71^{\circ}$ $38^{\prime} 42^{\prime \prime}$ W; Fig. 1). Conguillío features similar tree species composition when compared to Nahuelbuta, with mixed and pure Nothofagaceae and Araucaria araucana, but is relatively well connected with other similar forests along the Andes (AguileraBetti et al. 2017, Soto 2019).

To help inform the conservation status of this species, we compared samples of Magellanic Woodpeckers from Nahuelbuta and Conguillío national parks, using measures of genetic variability, inbreeding, and population structure, to understand the possible genetic consequences of historic deforestation in this region. We predicted that (1) isolated populations in Nahuelbuta 
Fig. 1. Maps showing the study area within the northern extent of Magellanic Woodpecker's (Campephilus magellanicus) distribution. The left map shows the two sampled national parks and the remnant native forests, illustrating the extensive deforestation in the lowlands between the two main mountain ranges. Other land-cover types such as agriculture, urban areas, and exotic plantations are labeled as 'Other'. The upper-right map shows the Magellanic Woodpecker's distribution in southern South America (grey area) and the northern extent of the range where both national parks are located. The lower-right map shows the Chilean remnants of native forests in the northern extent of the South American temperate forests and the geographical extent of the left panel.
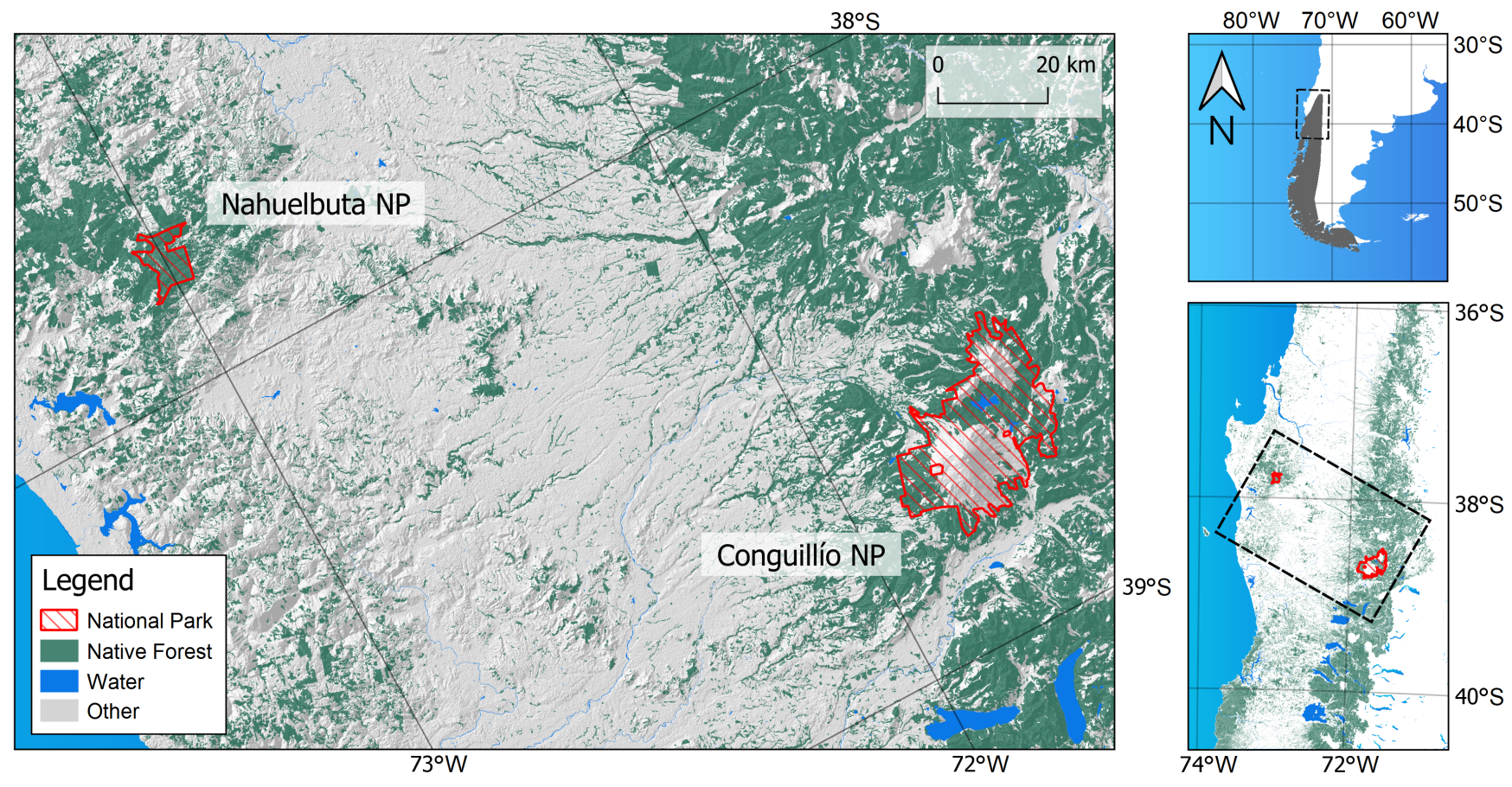

would have lower genetic diversity and greater levels of inbreeding than Conguillío, and (2) our two populations would show signs of genetic divergence.

\section{METHODS}

\section{Study sites and sampling}

A total of 33 Magellanic Woodpecker individuals were sampled during austral spring (September to December) of 2017 in Nahuelbuta $(\mathrm{N}=14)$ and Conguillío $(\mathrm{N}=19)$, central-southern Chile (Fig. 1). Nahuelbuta is the only protected area within the coastal mountain range that includes $A$. araucana, covering 61.91 $\mathrm{km}^{2}(98.2 \%)$ of native forest and includes shrub vegetation in degraded forest. Conguillío $\left(545 \mathrm{~km}^{2}\right)$, in the Andes Mountains, presents a native forest cover of $230.72 \mathrm{~km}^{2}(42.3 \%)$ and other species such as cushion plants, mosses, perennial grasses, scrub, and lichens growing on volcanic rocks (CONAF 2019).

Birds were captured using mist nets $(18 \mathrm{~m}$ long $\times 3 \mathrm{~m}$ high $)$ and marked with uniquely numbered metal bands (National Band and Tag Co., Newport, Kentucky, USA; Porzana Ltd, UK, provided by Servicio Agrícola y Ganadero de Chile). Before release, a small blood sample was obtained by brachial venipuncture (ca. $75 \mu \mathrm{L}$ ) and stored on FTA cards (Whatman ${ }^{\circledR}$ ) for subsequent molecular analysis.

\section{DNA sequencing}

We generated single nucleotide polymorphisms (SNPs) through a double-digest restriction site-associated DNA sequencing (ddRAD-seq) method, following the protocol described in Thrasher et al. (2018). We isolated genomic DNA with the DNeasy Blood and Tissue kit (Qiagen, Valencia, CA, USA) following the manufacturer's protocols. Briefly, we digested 200 ng genomic DNA from each individual with the enzymes SbfI and MspI, and ligated adapters on both the $5^{\prime}$ and $3^{\prime}$ ends. After digestion and ligation, these samples were pooled in groups of 19-20, based on unique barcodes present in the $5^{\prime}$ adapters. We subsequently selected DNA fragments in the 400-700 bp range for each pool separately using BluePippin (Sage Science). We added Illumina index groups and enriched our libraries through PCR. Finally, we combined each pool in equimolar ratios to create a single library for sequencing (together with samples from other projects) on one lane of an Illumina NextSeq 500 in mid output mode (single-end $151 \mathrm{bp}$ ). Sequencing was conducted at the Cornell Institute of Biotechnology.

\section{Bioinformatics and assembly of RAD loci}

We obtained an average of $0.57 \pm 0.2$ million reads per individual. We assessed read quality using FastQC version 0.11 .6 (https:// www.bioinformatics.babraham.ac.uk/projects/fastqc/) and decided to exclude the last $4 \mathrm{bp}$ on the $3^{\prime}$ end, which tended to show 
comparatively lower average quality calls by trimming sequences to $147 \mathrm{bp}$ using fast $\mathrm{X}$ trimmer (Gordon and Hannon 2017). We subsequently discarded reads with bases below a Phred quality score of $10(90 \%$ call accuracy) or with more than $5 \%$ between 10 and 20 (99\% call accuracy) using fastq_quality_filter (fastxToolkit). We demultiplexed the reads using the process_radtags module from the stacks pipeline version 1.48 (Catchen et al. 2013) obtaining files with sequences exclusive to each individual. All sequences were trimmed to $140 \mathrm{bp}$, the length of the shortest sequences after the 5-7 bp inline barcodes used for multiplexing was removed. We assembled sequences into RAD loci using the de novo pipeline from stacks (ustacks/cstacks/sstacks), requiring a minimum depth of coverage of 5 reads (m parameter) and allowing up to 5 mismatches between different alleles within individuals ( $\mathrm{M}$ parameter) or among individuals ( $\mathrm{n}$ parameter; Thrasher et al. 2018). We ran the rxstacks error correction module and a final iteration of cstacks/sstacks. This bioinformatics pipeline generated a catalog of 21,716 RAD loci from which we exported SNPs in different formats for downstream analyses using the population module from stacks, allowing up to $20 \%$ missing data per locus and requiring a minimum depth of coverage of $10 \times$. We exported both all the SNPs from the RAD loci that passed our filtering criteria (2669 SNPs) and only the first SNP from each rad locus to avoid including tightly linked markers (1674 SNPs).

\section{Population genomic analyses}

We calculated summary statistics for each population and FST between populations using the population module in Stacks. We used four methods to analyze our SNP data: a principal component analysis (PCA) with the SNPrelate R package version 3.3 (Zheng et al. 2012), the clustering software STRUCTURE version 2.3.4 (Pritchard et al. 2000), the haplotype-based clustering analysis implemented in fineRADstructure $\mathrm{v} 0.2$ (Malinsky et al. 2018), and we built a Maximum Likelihood phylogenetic tree in RaxML version 8.2.4 (Stamatakis 2014). For the principal component analysis and the phylogenetic tree, we used the dataset of 2669 SNPs, and for the STRUCTURE analysis, we used a single SNP per RAD locus (total of 1674 SNPs) to avoid using highly linked SNPs. The fineRADstructure analysis used haplotype information from 7207 variant and invariant RAD loci, which contained the 2669 SNPs used in other analyses. For the STRUCTURE analysis, we implemented the admixture ancestry model and used correlated allele frequencies, running the program for 750,000 generations, discarding the first 250,000 as burn-in. We conducted 10 runs exploring values of $\mathrm{K}$ from 1 to 5 , with a different random seed per iteration. We determined the most likely value of $\mathrm{K}$ in STRUCTURE HARVESTER version 0.6.94 (Earl and vonHoldt 2012), following the methods described by Evanno et al. (2005). Different iterations from the same $\mathrm{K}$ value were combined in CLUMPP version 1.1.2 (Jakobsson and Rosenberg 2007) and displayed using DISTRUCT version 1.1 (Rosenberg 2004). We ran the fineRADstructure analysis under default parameters, excluding one individual from Conguillío with higher than average missing data. We built the Maximum Likelihood phylogenetic tree from our SNP data by implementing the ASC_GTRGAMMA model and the Lewis correction for ascertainment bias. We included 3 individuals from a distant population from Navarino Island (sequenced for a different project) as the outgroup to root the phylogeny and conducted 500 bootstrap replicates to assess node support. This analysis uses loci in which both alleles are found in homozygosity in at least 1 individual, allowing us to retain 1078 SNPs in our final alignment. Finally, we attempted to reconstruct the demographic history of the two populations using (G-PhoCS) version 1.2.2 (Gronau et al. 2011), yet despite using various strategies to conduct the analysis (e.g., subsampling individuals or excluding migration estimates), we did not observe convergence in the different parameters when inspecting the traces in Tracer 1.7 (Rambaut et al. 2018). It is possible that the divergence among these populations is too shallow for the model to accurately estimate the different demographic parameters and we, therefore, do not discuss these results.

\section{RESULTS}

We recovered 2669 SNPs in 1674 RAD loci across all individuals. Private alleles (PA), percent polymorphic loci ( $\% \mathrm{PL})$, nucleotide diversity $(\mathrm{Pi})$, and both observed ( $\mathrm{Ho}$ ) and expected $(\mathrm{He})$ heterozygosity levels were lower in Nahuelbuta compared to Conguillío (Table 1). This pattern remained after randomly subsampling individuals from the Conguillío population to the same number of individuals from the Nahuelbuta population (Appendix 1). For each population, the expected and observed levels of heterozygosity were similar. Consequently, FIS values were close to zero and similar for both populations (Table 1) suggesting that these populations are not inbred. Our samples formed two clusters, coinciding with the sampling sites, in a PCA derived from 2669 SNPs. The first two principal components (PC1 and PC2) explained $7.03 \%$ and $5.10 \%$ of the total variance, respectively. The $\mathrm{PC} 1$ shows a significant separation of the two subpopulations (i.e., Nahuelbuta and Coguillío; Fig. 2A). The STRUCTURE analysis derived from 1674 SNPs (a single SNP per RAD locus) was consistent with the PCA in showing differentiation between Nahuelbuta and Conguillío, yet some individuals showed low levels of admixture (Fig. 2B). Higher values of $\mathrm{K}$ were not supported in our Structure analysis (Appendix 2). Results from fineRADstructure, a haplotype-based analysis, also supported the genetic differentiation between Nahuelbuta and Coguillío, showing signals of increased coancestry within each subpopulation (Appendix 3). The average FST value between Nahuelbuta and Conguillío was 0.04 (range 0-0.66 across all loci; Fig. 2C) suggesting a relatively low differentiation between both populations. Finally, phylogenetic analysis using our SNP data, shows that the Nahuelbuta population forms a clade that is nested within the individuals from Conguillío (Fig. 3), a pattern consistent with the Nahuelbuta population being derived from the Conguillío population.

Table 1. Genetic variability in Magellanic Woodpecker (Campephilus magellanicus) determined using ddRAD. The table includes sample size (n), number of private alleles (PA), \% polymorphic loci (\%PL), nucleotide diversity (Pi), levels of observed (Ho) and expected (He) heterozygosity, and inbreeding values (FIS by sampling site).

\begin{tabular}{lccccccc}
\hline \hline Site & $\mathrm{n}$ & $\mathrm{PA}$ & $\% \mathrm{PL}$ & $\mathrm{Pi}$ & $\mathrm{H}_{\mathrm{O}}$ & $\mathrm{H}_{\mathrm{e}}$ & $\mathrm{FIS}$ \\
\hline Nahuelbuta & 14 & 296 & 0.18 & 0.20 & 0.22 & 0.19 & -0.03 \\
Conguillío & 20 & 656 & 0.22 & 0.22 & 0.23 & 0.22 & -0.01 \\
\hline
\end{tabular}


Fig. 2. Population structure of the Magellanic Woodpecker (Campephilus magellanicus) in the Valdivian ecoregion from samples collected in Nahuelbuta $(\mathrm{n}=14)$ and Conguillío $(\mathrm{n}=$ 20) national parks. (A) The principal component analysis (PCA) based on 2668 SNPs. Circles representing individuals and colors denoting sites of origin. (B) Structure plot of Magellanic Woodpeckers sampled in Nahuelbuta $(\mathrm{n}=14)$ and Conguillío $(\mathrm{n}=19)$ national parks in the Valdivian ecoregion. Each individual is represented by a vertical bar broken into different colored genetic clusters, with length proportional to the probability of assignment to each cluster. (C) Frequency histogram of FST values across 2668 SNPs, with the average value $(0.04)$ indicated by the vertical red line.
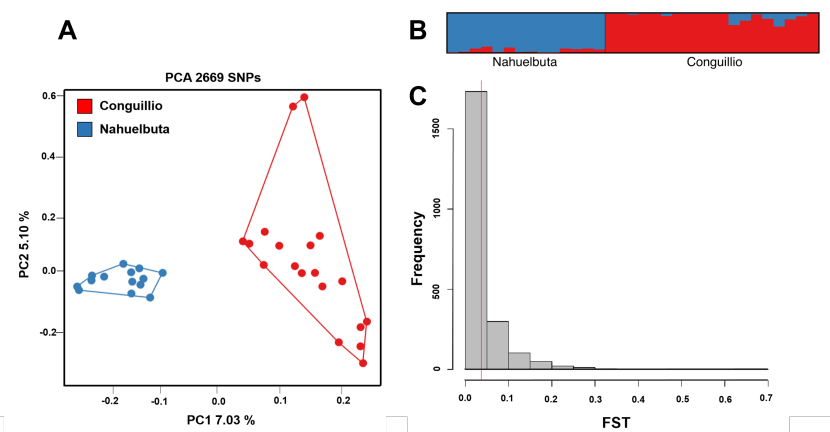

\section{DISCUSSION}

The genetic variability of populations depends upon a wide range of factors, including dispersal capacity (Rappole 2013), the degree of ecological specialization of the species (Anders et al. 1998, Crochet 2000, Harris and Reed 2002), and landscape attributes (Bélisle and St. Clair 2001, McRae 2006). In this study, we show differences in genetic variability and evidence of population structure between Magellanic Woodpeckers occupying Nahuelbuta and Conguillío national parks in the northern extent of the Valdivian ecoregion in Chile. Specifically, we found a low number of private alleles and polymorphic loci as well as reduced levels of nucleotide diversity and heterozygosity in Nahuelbuta (Table $1)$, which are consistent with lower genetic variability.

Although Magellanic Woodpeckers can fly long distances and overcome potential barriers to dispersal (Winkler et al. 2016), they also are reluctant to cross open areas and venture into a deforested matrix. Research on the movement behavior of Magellanic Woodpeckers shows that dominant males determine their movement trajectory and patch residence times according to observable and memorized information of local habitat quality (Vergara et al. 2015, 2016), suggesting that individuals avoid the use of a hostile matrix to perform dispersal, similarly to other woodpecker species (e.g., Pasinelli and Walters 2002, Trainor et al. 2013). Hence, evidence suggests that lower genetic variability values observed in Nahuelbuta may be a consequence of the open matrix surrounding this area, which would limit the ability of the forest-dependent woodpeckers to disperse (Gorman 2014, Lammertink 2014).
Fig. 3. Phylogenetic tree showing the Nahuelbuta population forming a nested clade within Conguillío. Numbers denote bootstrap support for the relevant clades.

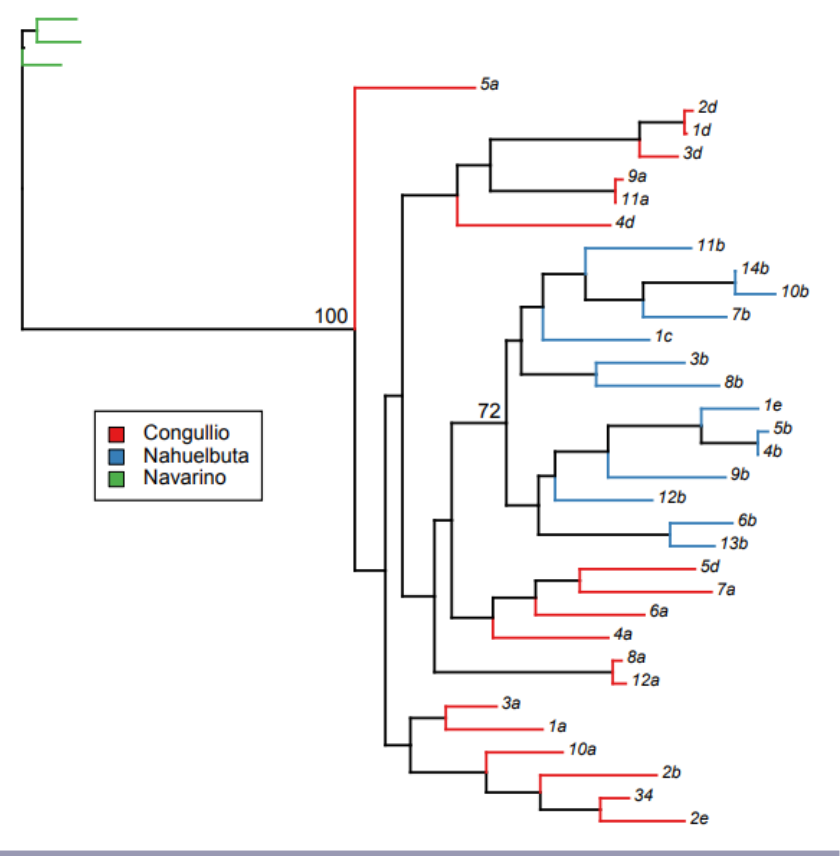

Although we did not find evidence for inbreeding (FIS $>0$ ) in these populations (Table 1), it is important to note that inbreeding is a gradual phenomenon and likely to increase over time in small and/or closed populations in which mating individuals will have, eventually, some degree of kinship (Ralls et al. 2014, Chen et al. 2016). Across time, inbreeding depression, defined as the decline in fitness observed in inbred progeny (Keller and Waller 2002), may occur in these populations because of the overall increase in homozygosity and exposure of recessive deleterious alleles (Charlesworth and Charlesworth 1987). Evidence in birds has shown that inbreeding depression negatively affects survival and reproductive success (Bensch et al. 1994, Spottiswoode and Møller 2004, Cassinello 2005, Szulkin et al. 2007, Hemmings et al. 2012). Indeed, several studies have concluded that dispersal barriers often promote inbreeding over time (Van Tienderen and Van Noordwijk 1988, Daniels and Walters 2000, Glémin et al. 2003, Szulkin and Sheldon 2008). Consequently, if Magellanic Woodpeckers avoid using a deforested and presumably hostile matrix, inbreeding may gradually rise in the Nahuelbuta population to the point of reducing fitness.

The low level of genetic structure detected between Nahuelbuta and Conguillío samples suggests that divergence between both clusters is relatively recent (Freeland et al. 2012). Unfortunately, demographic models were not able to infer the divergence time between both clusters, likely because of low differentiation between populations and the long generation time of the species (Lois et al. 2020). However, the phylogenetic tree showed that the Nahuelbuta clade is nested within the individuals from Conguillío, indicating recent isolation. Deforestation during 
Avian Conservation and Ecology 15(2): 19

recent decades has likely reduced connectivity among remnant forests in ways that affect population structure (Vergara et al. 2017).

Collectively, our results suggest that Nahuelbuta woodpeckers seem to be in an initial phase of loss of genetic variability, likely due to their reluctance to cross a deforested matrix (Lammertink 2014). If Magellanic Woodpeckers remain isolated in Nahuelbuta, we predict that genetic variability will further decline and may eventually compromise their ability to adapt to environmental change.

According to Chile's national legislation, the northern extent of the Valdivian ecoregion comprises approximately 3,184,200 ha, from which 964,152 ha (3.02\%) are native forests (CONAF 2019). From these native forests, $28.54 \%(275,196 \mathrm{ha})$ corresponds to mature forests suitable for Magellanic Woodpeckers, located mainly in the Andes Mountain range (CONAF 2020). Nowadays, $41 \%(112,830 \mathrm{ha})$ of them are protected by The National System of State Protected Wild Areas (SNASPE by its Spanish acronym), while 59\% (162,365 ha) belong to other fiscal agencies and/or private companies (CONAF 2019). In the coastal region of the Nahuelbuta mountain range, the Nahuelbuta National Park protects less than $1 \%$ (1790 ha) of the remaining mature forest, compared to the nearly $15 \%(40,936 \mathrm{ha})$ owned by timber companies (CONAF 2015, Soto 2019).

Within this context, our results provide further evidence that the persistence of the Magellanic Woodpeckers in the Nahuelbuta Mountain range remains uncertain. We recommend that conservation efforts focus on engaging the public and private sectors to protect and restore native mature forests in ways that increase structural connectivity at regional or national scales.

Responses to this article can be read online at: http://www.ace-eco.org/issues/responses.php/1692

\section{Acknowledgments:}

We thank Javiera Encina and Katherine Martinez for their collaboration during fieldwork and Amy Wynia for providing us with three blood samples from Navarino Island to perform the rooting of our phylogenetic tree. Fieldwork in protected areas was possible thanks to people from Parque Nacional Conguillio and Parque Nacional Nahuelbuta. We thank Marcelo Saavedra and Basilio Guiñez from CONAF Araucania. We thank Wesley Hochachka from the Cornell Lab of Ornithology and Mario Nazar for their technical support. We thank Bronwyn Butcher and Irby Lovette for facilitating the generation of genomic data. We thank Paula Castillo and two anonymous reviewers for valuable comments on an earlier draft of the manuscript. Funding was provided by Universidad de Las Américas-Chile (grant $N^{\circ}$ PI0142017) to Dr. Yanina Poblete and graduate fellowships Advanced Human Capital Program, CONICYT, to Dr. Gerardo Soto. This study was supported by the Rufford Foundation, the Andrew W. Mellon Foundation, the Athena Grant from the Cornell Lab of Ornithology, and the Latin research American Studies Program from the Mario Einaudi Center for International Studies.

\section{LITERATURE CITED}

Aguilera-Betti, I., A. A. Muñoz, D. Stahle, G. Figueroa, F. Duarte, Á. González-Reyes, D. Christie, A. Lara, M. E. González, P. R. Sheppard, D. Sauchyn, A. Moreira-Muñoz, I. ToledoGuerrero, M. Olea, P. Apaz, and A. Fernandez. 2017. The first millennium-age Araucaria araucana in Patagonia. Tree-Ring Research 73:53-56. https://doi.org/10.3959/1536-1098-73.1.53

Allendorf, F. W., and G. Luikart. 2007. Units of conservation. Pages 380-420 in F. W. Allendorf and G. Luikart, editors. Conservation and the genetics of populations. Blackwell, Oxford, UK.

Altamirano, T. A., J. T. Ibarra, K. Martin, and C. Bonacic. 2017. The conservation value of tree decay processes as a key driver structuring tree cavity nest webs in South American temperate rainforests. Biodiversity and Conservation 26:2453-2472. https:// doi.org/10.1007/s10531-017-1369-x

Anders, A. D., J. Faaborg, and F. R. Thompson, III. 1998. Postfledging dispersal, habitat use, and home-range size of Juvenile Wood Thrushes. Auk 115:349-358. https://doi. org/10.2307/4089193

Arango, X., R. Rozzi, F. Massardo, C. B. Anderson, and T. Ibarra. 2007. Descubrimiento e implementación del pájaro carpintero gigante (Campephilus magellanicus) como especie carismática: una aproximación biocultural para la conservación en la Reserva de Biosfera Cabo de Hornos. Magallania 35:71-88. https://doi. org/10.4067/S0718-22442007000200006

Assandri, G., A. Bernardi, A. Schmoliner, G. Bogliani, P. Pedrini, and M. Brambilla. 2018. A matter of pipes: Wryneck Jynx torquilla habitat selection and breeding performance in an intensive agroecosystem. Journal of Ornithology 159:103-114. https://doi.org/10.1007/s10336-017-1479-y

Bélisle, M., and C. St. Clair. 2001. Cumulative effects of barriers on the movements of forest birds. Conservation Ecology 5(2):9. [online] URL: http://www.consecol.org/vol5/iss2/art9/

Bensch, S., D. Hasselquist, and T. von Schantz. 1994. Genetic similarity between parents predicts hatching failure: nonincestuous inbreeding in the Great Reed Warbler? Evolution 48:317-326. https://doi.org/10.1111/j.1558-5646.1994.tb01314.x

Billerman, S. M., M. A. Murphy, and M. D. Carling. 2016. Changing climate mediates sapsucker (Aves: Sphyrapicus) hybrid zone movement. Ecology and Evolution 6:7976-7990. https://doi. org/10.1002/ece3.2507

Blackwell, B. F., P. D. Doerr, J. M. Reed, and J. R. Walters. 1995. Inbreeding rate and effective population size: a comparison of estimates from pedigree analysis and a demographic model. Biological Conservation 71:299-304. https://doi.org/10.1016/0006-3207 (94)00050-Z

Botero-Delgadillo, E., V. Quirici, Y. Poblete, M. Acevedo, É. Cuevas, C. Bravo, M. Cragnolini, R. Rozzi, E. Poulin, J. C. Mueller, B. Kempenaers, and R. A. Vásquez. 2020. Range-wide genetic structure in the thorn-tailed rayadito suggests limited gene flow towards peripheral populations. Scientific Reports 10:9409. https://doi.org/10.1038/s41598-020-66450-7 
Bruggeman, D. J., T. Wiegand, and N. Fernández. 2010. The relative effects of habitat loss and fragmentation on population genetic variation in the Red-cockaded Woodpecker (Picoides borealis). Molecular Ecology 19:3679-3691. https://doi.org/10.1111/ j.1365-294X.2010.04659.x

Cassinello, J. 2005. Inbreeding depression on reproductive performance and survival in captive gazelles of great conservation value. Biological Conservation 122:453-464. https://doi. org/10.1016/j.biocon.2004.09.006

Catchen, J., P. A. Hohenlohe, S. Bassham, A. Amores, and W. A. Cresko. 2013. Stacks: an analysis tool set for population genomics. Molecular Ecology 22:3124-3140. https://doi.org/10.1111/ mec. 12354

Charlesworth, D., and B. Charlesworth. 1987. Inbreeding depression and its evolutionary consequences. Annual Review of Ecology and Systematics 18:237-268. https://doi.org/10.1146/ annurev.es.18.110187.001321

Chazarreta, M., V. Ojeda, and J. Lammertink. 2012. Morphological and foraging behavioral differences between sexes of the Magellanic Woodpecker (Campephilus Magellanicus). Ornitologia Neotropical 23:529-544.

Chen, N., E. J. Cosgrove, R. Bowman, J. W. Fitzpatrick, and A. G. Clark. 2016. Genomic consequences of population decline in the endangered Florida Scrub-Jay. Current Biology 26:2974-2979. https://doi.org/10.1016/j.cub.2016.08.062

Corporación Nacional Forestal (CONAF). 2015. Caracterización de nidos de Carpintero negro (Campephilus magellanicus) en la Areas silvestres protegidas. Ministerio de Agricultura, Gobierno de Chile, Santiago, Chile. [online] URL: https://www.conaf.cl/wpcontent/files_mf/1443471722InformecaracterizacionnidosCarpinteroNegro2015.pdf

Corporación Nacional Forestal (CONAF). 2019. Sistema de información territorial de SNAPES. Ministerio de Agricultura, Gobierno de Chile, Santiago, Chile. [online] URL: http://sit. conaf.cl/

Corporación Nacional Forestal (CONAF). 2020. Catastro de los recursos vegetacionales nativos de Chile al año 2019. Departamento Monitoreo de Ecosistemas Forestales, GEF Santiago, Chile. [online] URL: https://www.conaf.cl/nuestrosbosques/bosques-en-chile/catastro-vegetacional/

Cox, A. S., and D. C. Kesley. 2012. Reevaluating the cost of natal dispersal: post-fledging survival of Red-bellied Woodpeckers. Condor 114:341-347. https://doi.org/10.1525/cond.2012.110070

Crochet, P.-A. 2000. Genetic structure of avian populations allozymes revisited. Molecular Ecology 9:1463-1469. https://doi. org/10.1046/j.1365-294x.2000.01026.x

Dale, S. 2001. Female-biased dispersal, low female recruitment, unpaired males, and the extinction of small and isolated bird populations. Oikos 92:344-356. https://doi.org/10.1034/ j.1600-0706.2001.920217.x

Daniels, S. J., and J. R. Walters. 2000. Inbreeding depression and its effects on natal dispersal in Red-Cockaded Woodpeckers. Condor 102:482-491. https://doi.org/10.1093/condor/102.3.482
DiLeo, M. F., and H. H. Wagner. 2016. A landscape ecologist's agenda for landscape genetics. Current Landscape Ecology Reports. 1:115-126. https://doi.org/10.1007/s40823-016-0013-x

Dinerstein, E., D. M. Olson, D. Graham, A. L. Webster, S. A. Primm, M. P. Bookbinder, G. Ledec, and World Wildlife Fund. 1995. Ecoregions of Latin America and the Caribbean. $A$ conservation assessment of the terrestrial ecoregions of Latin America and the Caribbean. World Wildlife Foundation and The World Bank, Washington, D.C., USA. https://doi. org/10.1596/0-8213-3295-3

Earl, D. A., and B. M. vonHoldt. 2012. STRUCTURE HARVESTER: a website and program for visualizing STRUCTURE output and implementing the Evanno method. Conservation Genetics Resources 4:359-361. https://doi. org/10.1007/s12686-011-9548-7

Ellegren, H., A. Carlson, and I. Stenberg. 1999. Genetic structure and variability of White-backed Woodpecker (Dendrocopos leucotos) populations in northern Europe. Hereditas 130:291-299. https://doi.org/10.1111/j.1601-5223.1999.00291.x

England, P. R., G. H. R. Osler, L. M. Woodworth, M. E. Montgomery, D. A. Briscoe, and R. Frankham. 2003. Effects of intense versus diffuse population bottlenecks on microsatellite genetic diversity and evolutionary potential. Conservation Genetics 4:595-604. https://doi.org/10.1023/A:1025639811865

Evanno, G., S. Regnaut, and J. Goudet. 2005. Detecting the number of clusters of individuals using the software STRUCTURE: a simulation study. Molecular Ecology 14:2611-2620. https://doi.org/10.1111/j.1365-294X.2005.02553. $\mathrm{x}$

Fisher, R. A. 1958. The genetical theory of natural selection. Dover, New York, New York, USA. https://doi.org/10.5962/bhl. title. 27468

Fitzpatrick, J. W., M. Lammertink, M. D. Luneau, Jr., T. W. Gallagher, B. R. Harrison, G. M. Sparling, K. V. Rosenberg, R. W. Rohrbaugh, E. C. H. Swarthout, P. H. Wrege, S. Barker Swarthout, M. S. Dantzker, R. A. Charif, T. R. Barksdale, J. V. Remsen, Jr., S. D. Simon, and D. Zollner. 2006. Clarifications about current research on the status of Ivory-billed Woodpecker (Campephilus principalis) in Arkansas. Auk 123:587-593. https:// doi.org/10.1093/auk/123.2.587

Foley, J. A., R. DeFries, G. P. Asner, C. Barford, G. Bonan, S. R. Carpenter, F. S. Chapin, M. T. Coe, G. C. Daily, H. K. Gibbs, J. H. Helkowski, T. Holloway, E. A. Howard, C. J. Kucharik, C. Monfreda, J. A. Patz, I. C. Prentice, N. Ramankutty, and P. K. Snyder. 2005. Global consequences of land use. Science 309:570-574. https://doi.org/10.1126/science.1111772

Frankham, R. 1995. Inbreeding and extinction: a threshold effect. Conservation Biology 9:792-799. https://doi.org/10.1046/ j.1523-1739.1995.09040792.x

Frankham, R., J. D. Ballou, K. Ralls, M. D. B. Eldridge, M. R. Dudash, C. B. Fenster, R. C. Lacy, and P. Sunnucks. $2017 a$. Genetic problems in small isolated populations. Pages 15-40 in Genetic management of fragmented animal and plant populations. Oxford University Press, Oxford, UK. 
Frankham, R., J. D. Ballou, K. Ralls, M. D. B. Eldridge, M. R. Dudash, C. B. Fenster, R. C. Lacy, and P. Sunnucks. $2017 b$. Population fragmentation cause inadequate gene flow and increases extinction risk. Pages 87-112 in Genetic management of fragmented animal and plant populations. Oxford University Press, Oxford, UK.

Freeland, J. R., H. Kirk, and S. Petersen. 2012. Genetic analysis of multiple populations. Pages 129-177 in Molecular ecology. Second edition. Wiley, Hoboken, New Jersey, USA. https://doi. org/10.1002/9780470979365.ch4

Glémin, S., J. Ronfort, and T. Bataillon. 2003. Patterns of inbreeding depression and architecture of the load in subdivided populations. Genetics 165:2193-2212. [online] URL: https://www. genetics.org/content/165/4/2193

Gordon, A., and G. Hannon. 2017. Fastx-toolkit. FASTQ/A short-reads pre-processing tools 2010. Cold Spring Harbor Laboratory, Long Island, New York, USA. [online] URL: http:// hannonlab.cshl.edu/fastx_toolkit/

Gorman, G. 2014. Woodpeckers of the world: the complete guide. Chistopher Helm-Bloomshury, London, UK.

Gronau, I., M. J. Hubisz, B. Gulko, C. G. Danko, and A. Siepel. 2011. Bayesian inference of ancient human demography from individual genome sequences. Nature Genetics 43:1031-1035. https://doi.org/10.1038/ng.937

Haig, S. M., J. R. Belthoff, and D. H. Allen. 1993. Examination of population structure in Red-cockaded Woodpeckers using DNA profiles. Evolution 47:185-194. https://doi.org/10.1111/ j.1558-5646.1993.tb01209.x

Haig, S. M., R. Bowman, and T. D. Mullins. 1996. Population structure of Red-cockaded Woodpeckers in south Florida: RAPDs revisited. Molecular Ecology 5:725-734. https://doi. org/10.1111/j.1365-294X.1996.tb00369.X

Harris, R. J., and J. M. Reed. 2002. Behavioral barriers to nonmigratory movements of birds. Annales Zoologici Fennici 39:275-290.

Hemmings, N. L., J. Slate, and T. R. Birkhead. 2012. Inbreeding causes early death in a passerine bird. Nature Communications 3:863. https://doi.org/10.1038/ncomms 1870

Ilsøe, S. K., W. D. Kissling, J. Fjeldså, B. Sandel, and J.-C. Svenning. 2017. Global variation in woodpecker species richness shaped by tree availability. Journal of Biogeography 44:1824-1835. https://doi.org/10.1111/jbi.13009

Jakobsson, M., and N. A. Rosenberg. 2007. CLUMPP: a cluster matching and permutation program for dealing with label switching and multimodality in analysis of population structure. Bioinformatics 23:1801-1806. https://doi.org/10.1093/bioinformatics/ btm233

Jiménez, J. E., R. D. Crego, G. E. Soto, I. Román, R. Rozzi, and P. M. Vergara. 2014. Potential impact of the alien American mink (Neovison vison) on Magellanic Woodpeckers (Campephilus magellanicus) in Navarino Island, southern Chile. Biological Invasions 16:961-966. https://doi.org/10.1007/s10530-013-0549-1
Keller, L. F., and D. M. Waller. 2002. Inbreeding effects in wild populations. Trends in Ecology and Evolution 17:230-241. https:// doi.org/10.1016/S0169-5347(02)02489-8

Lammertink, M. 2014. Trends in threat status and priorities in conservation of the woodpeckers of the world. Acta Ornithologica 49:207-219. https://doi.org/10.3161/173484714X687109

Lammertink, M., and A. R. Estrada. 1995. Status of the Ivorybilled Woodpecker Campephilus principalis in Cuba: almost certainly extinct. Bird Conservation International 5:53-59. https:// doi.org/10.1017/S095927090000294X

Lande, R. 1994. Risk of population extinction from fixation of new deleterious mutations. Evolution 48:1460-1469. https://doi. org/10.1111/j.1558-5646.1994.tb02188.x

Lois, N. A., L. Campagna, U. Balza, M. J. Polito, K. Pütz, J. A. Vianna, A. Morgenthaler, E. Frere, R. Sáenz-Samaniego, A. Raya Rey, and B. Mahler. 2020. Metapopulation dynamics and foraging plasticity in a highly vagile seabird, the southern Rockhopper Penguin. Ecology and Evolution 10:3346-3355. https://doi. org/10.1002/ece3.6127

Malinsky, M., E. Trucchi, D. J. Lawson, and D. Falush. 2018. RADpainter and fineRADstructure: population inference from RADseq data. Molecular Biology and Evolution 35:1284-1290. https://doi.org/10.1093/molbev/msy023

McRae, B. H. 2006. Isolation by resistance. Evolution 60:1551-1561. https://doi.org/10.1111/j.0014-3820.2006.tb00500. $\mathrm{x}$

Mermod, M., T. S. Reichlin, R. Arlettaz, and M. Schaub. 2009. The importance of ant-rich habitats for the persistence of the Wryneck Jynx torquilla on farmland. Ibis 151(4):731-742. https:// doi.org/10.1111/j.1474-919X.2009.00956.x

Myers, N., R. A. Mittermeier, C. G. Mittermeier, G. A. B. Fonseca, and J. Kent. 2007. Biodiversity hotspots for conservation priorities. Nature 403:853-858. https://doi.org/10.1038/35002501

Ojeda, V. S. 2004. Breeding biology and social behaviour of Magellanic Woodpeckers (Campephilus magellanicus) in Argentine Patagonia. European Journal of Wildlife Research 50:18-24. https://doi.org/10.1007/s10344-003-0029-5

Ojeda, V. S., and M. L. Chazarreta. 2006. Provisioning of Magellanic Woodpecker (Campephilus magellanicus) nestlings with vertebrate prey. Wilson Journal of Ornithology 118:251-254. https://doi.org/10.1676/05-014.1

Ojeda, V., and L. Chazarreta. 2014. Home range and habitat use by Magellanic Woodpeckers in an old-growth forest of Patagonia. Canadian Journal of Forest Research 44:1265-1273. https://doi. org/10.1139/cjfr-2013-0534

Olson, D. M., E. Dinerstein, E. D. Wikramanayake, N. D. Burgess, G. V. N. Powell, E. C. Underwood, J. A. D'amico, I. Itoua, H. E. Strand, J. C. Morrison, C. J. Loucks, T. F. Allnutt, T. H. Ricketts, Y. Kura, J. F. Lamoreux, W. W. Wettengel, P. Hedao, and K. R. Kassem. 2001. Terrestrial ecoregions of the world: a new map of life on Earth. BioScience 51:933-938. https://doi.org/10.1641/0006-3568 (2001)051[0933:TEOTWA]2.0.CO;2 
Otero, L. 2006. La huella del fuego: historia de los bosques nativos: poblamiento y cambios en el paisaje del sur de Chile. Pehuén, Santiago, Chile.

Palsbøll, P. J., M. Bérubé, and F. W. Allendorf. 2007. Identification of management units using population genetic data. Trends in Ecology and Evolution 22:11-16. https://doi.org/10.1016/j. tree.2006.09.003

Pasinelli, G., and J. R. Walters. 2002. Social and environmental factors affect natal dispersal and philopatry of male Redcockaded Woodpeckers. Ecology 83:2229-2239. https://doi. org/10.1890/0012-9658(2002)083[2229:SAEFAN]2.0.CO;2

Pritchard, J. K., M. Stephens, and P. Donnelly. 2000. Inference of population structure using multilocus genotype data. Genetic 155:945-959. [online] URL: https://www.genetics.org/content/155/2/945

Ralls, K., R. Frankham, and J. D. Ballou. 2014. Inbreeding and outbreeding. Reference Module in Life Sciences. https://doi. org/10.1016/b978-0-12-809633-8.02152-x

Rambaut, A., A. J. Drummond, D. Xie, G. Baele, and M. A. Suchard. 2018. Posterior summarization in Bayesian phylogenetics using Tracer 1.7. Systematic Biology 67:901-904. https://doi.org/10.1093/sysbio/syy032

Rappole, J. H. 2013. Connectivity and conservation. Pages 284-301 in The avian migrant: the biology of bird migration. Columbia University Press, New York, New York, USA.

Reed, J. M., P. D. Doerr, and J. R. Walters. 1988. Minimum viable population size of the Red-cockaded Woodpecker. Journal of Wildlife Management 52:385-391. https://doi.org/10.2307/3801578

Reed, J. M., J. R. Walters, T. E. Emigh, and D. E. Seaman. 1993. Effective population size in Red-cockaded Woodpeckers: population and model differences. Conservation Biology 7:302-308. https://doi.org/10.1046/j.1523-1739.1993.07020302.x

Rosenberg, N. A. 2004. DISTRUCT: a program for the graphical display of population structure. Molecular Ecology Notes 4:137-138. https://doi.org/10.1046/j.1471-8286.2003.00566.x

Schiegg, K., S. J. Daniels, J. R. Walters, J. A. Priddy, and G. Pissinelli. 2006. Inbreeding in Red-cockaded Woodpeckers: effects of natal dispersal distance and territory location. Biological Conservation 131:544-552. https://doi.org/10.1016/j. biocon.2006.03.001

Servicio Agrícola y Ganadero. 2015. La ley de caza y su reglamento. Servicio Agrícola y Ganadero (SAG), Santiago, Chile. [online] URL: https://www.sag.gob.cl/sites/default/files/ ley_de_caza_y_su_reglamento_2015.pdf

Short L. L. 1982. Woodpeckers of the world. Delaware Museum of Natural History, Greenville, Delaware, USA.

Soto, G. E. 2019. Multi-scale influence of habitat and disturbance on the spatial ecology of Magellanic Woodpeckers (Campephilus magellanicus). Dissertation, Cornell University, Ithaca, New York, USA.

Soto, G. E., C. G. Pérez-Hernández, I. J. Hahn, A. D. Rodewald, and P. M. Vergara. 2017. Tree senescence as a direct measure of habitat quality: linking red-edge vegetation indices to space use by Magellanic Woodpeckers. Remote Sensing of Environment 193:1-10. https://doi.org/10.1016/j.rse.2017.02.018

Soto, G. E., P. M. Vergara, and A. D. Rodewald. 2018. The fruit of competition: seed dispersal by Magellanic Woodpeckers in the threatened Valdivian Rainforest. Ecology 99:2617-2620. https:// doi.org/10.1002/ecy.2454

Soto, G. E., P. M. Vergara, A. Smiley, M. E. Lizama, D. MoreiraArce, and R. A. Vásquez. 2016. Lethal agonistic behavior between two male Magellanic Woodpeckers Campephilus magellanicus observed in the Cape Horn area. Wilson Journal of Ornithology 128:180-184. https://doi.org/10.1676/1559-4491-128.1.180

Spottiswoode, C., and A. P. Møller. 2004. Genetic similarity and hatching success in birds. Proceedings of the Royal Society B. Biological Sciences 271:267-272. https://doi.org/10.1098/rspb.2003.2605

Stamatakis, A. 2014. RAxML version 8: a tool for phylogenetic analysis and post-analysis of large phylogenies. Bioinformatics 30:1312-1313. https://doi.org/10.1093/bioinformatics/btu033

Stangel, P. W., M. R. Lennartz, and M. H. Smith. 1992. Genetic variation and population structure of Red-cockaded Woodpeckers. Conservation Biology 6:283-292. https://doi. org/10.1046/j.1523-1739.1992.620283.x

Szulkin, M., D. Garant, R. H. Mccleery, and B. C. Sheldon. 2007. Inbreeding depression along a life-history continuum in the Great Tit. Journal of Evolutionary Biology 20:1531-1543. https://doi. org/10.1111/j.1420-9101.2007.01325.x

Szulkin, M., and B. C. Sheldon. 2008. Dispersal as a means of inbreeding avoidance in a wild bird population. Proceedings of the Royal Society B: Biological Sciences 275:703-711. https://doi. org/10.1098/rspb.2007.0989

Tremblay, J. A., J. Ibarzabal, C. Dussault, and J.-P. L. Savard. 2009. Habitat requirements of breeding Black-backed Woodpeckers (Picoides arcticus) in managed, unburned boreal forest. Avian Conservation and Ecology 4(1):2. https://doi. org/10.5751/ACE-00297-040102

Thrasher, D. J., B. G. Butcher, L. Campagna, M. S. Webster, and I. J. Lovette. 2018. Double-digest RAD sequencing outperforms microsatellite loci at assigning paternity and estimating relatedness: a proof of concept in a highly promiscuous bird. Molecular Ecology Resources 18:953-965. https://doi. org/10.1111/1755-0998.12771

Trainor, A. M., J. R. Walters, W. F. Morris, J. Sexton, and A. Moody. 2013. Empirical estimation of dispersal resistance surfaces: a case study with Red-cockaded Woodpeckers Landscape Ecology 28:755-767. https://doi.org/10.1007/s10980-013-9861-5

Turner, I. M., and R. T. Corlett. 1996. The conservation value of small, isolated fragments of lowland tropical rain forest. Trends in Ecology and Evolution 11:330-333. https://doi.org/10.1016/0169-5347 (96)10046-X

Van Dyke, F. 2008. Conservation biology: foundations, concepts, applications. Springer, Berlin, Germany.

Van Tienderen, P. H., and A. J. Van Noordwijk. 1988. Dispersal, kinship and inbreeding in an island population of the Great Tit. Journal of Evolutionary Biology 1:117-137. https://doi. org/10.1046/j.1420-9101.1988.1020117.x 
Vergara, P. M., L. O. Meneses, M. Saavedra, F. E. Diaz, K. Norambuena, A. Fierro, A. D. Rodewald, and G. E. Soto. 2017. Magellanic Woodpeckers in three national parks of centralsouthern Chile: habitat effects and population variation over the last two decades. Avian Conservation and Ecology 12(2):15. https:// doi.org/10.5751/ACE-01106-120215

Vergara, P. M., S. Saura, C. G. Pérez-Hernández, and G. E. Soto. 2015. Hierarchical spatial decisions in fragmented landscapes: modeling the foraging movements of woodpeckers. Ecological Modelling 300:114-122. https://doi.org/10.1016/j.ecolmodel.2015.01.006

Vergara, P. M., G. E. Soto, D. Moreira-Arce, A. D. Rodewald, L. O. Meneses, and C. G. Pérez-Hernández. 2016. Foraging behaviour in magellanic woodpeckers is consistent with a multiscale assessment of tree quality. PLoS ONE 11:1-22. https://doi. org/10.1371/journal.pone.0159096

Vergara, P. M., G. E. Soto, A. D. Rodewald, and M. Quiroz. 2019. Behavioral switching in Magellanic Woodpeckers reveals perception of habitat quality at different spatial scales. Landscape Ecology 34:79-92. https://doi.org/10.1007/s10980-018-0746-5

Vuilleumier, F. 1985. Forest birds of Patagonia: ecological geography, speciation, endemism, and faunal history. Ornithological Monographs 36:255-304. https://doi.org/10.2307/40168287

Walters, J. R. 1991. Application of ecological principles to the management of endangered species: the Case of the Redcockaded Woodpecker. Annual Review of Ecology, Evolution, and Systematics 22:505-523. https://doi.org/10.1146/annurev.

es.22.110191.002445

Winkler, D. W., J. Shamoun-Baranes, and T. Piersma. 2016. Avian migration and dispersal. Pages 453-494 in I. Lovette and J. W. Fitzptrick, editors. Handbook of bird biology. The Cornell Lab of Ornithology, Ithaca, New York, USA. Wiley, Hoboken, New Jersey, USA.

Wright, S. 1978. Genetic variability in natural populations methods. Pages 83-107 in Evolution and the genetics of populations, Volume 4: variability within and among natural populations. University of Chicago Press, Chicago, Illinois, USA. https://doi. org/10.2307/2529965

Zheng, X., D. Levine, J. Shen, S. M. Gogarten, C. Laurie, and B. S. Weir. 2012. A high-performance computing toolset for relatedness and principal component analysis of SNP data. Bioinformatics 28:3326-3328. https://doi.org/10.1093/bioinformatics/ bts606

Editor-in-Chief: Alexander L.Bond Subject Editor: Scott ATaylor
Sponsored by the Society of Canadian Ornithologists and Birds Canada

Parrainée par la Société des ornithologistes du Canada et Oiseaux Canada

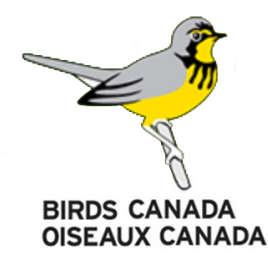




\section{Appendix 1.}

Table A1. Population genetic parameters obtained after randomly subsampling Conguillío individuals to match the sample size for Nahuelbuta $(\mathrm{N}=14)$. We obtain similar results to those reported in Table 1. Note that although we did not change the number of samples from Nahuelbuta, the values of some parameters changed slightly because the missing data filter is now applied to a different total number of individuals (and we only exported loci present in at least $80 \%$ of individuals).

\begin{tabular}{|c|c|c|c|c|c|c|}
\hline \multirow{3}{*}{ Parameters } & \multicolumn{3}{|c|}{ Population sizes } & \multirow{2}{*}{ Gene flow } \\
\cline { 2 - 3 } & Con & Nah & root & $\begin{array}{c}\text { Divergence } \\
\text { time }\end{array}$ & Con - N Nah & Nah -> Con \\
\hline \multirow{2}{*}{ Median } & 14025 & 0 & 144792.5 & 0 & 1.11 E-09 & 1.17 E-05 \\
L95\% CI & 14.5 & 0 & 133565 & 0 & 0 & 0 \\
U95\% CI & 101442.5 & 1.25 & 156235 & 0 & 2.96 & 0.32 \\
\hline
\end{tabular}




\section{Appendix 2.}

Figure A2. Exploration of the K values in Magellanic woodpecker samples. (A) Structure plots values of $\mathrm{K}$ from ranging from 2 to 5. (B) Likelihood and delta K sensu Evanno et al. 2005. Values of K beyond 2 are not supported.

A

Nahuelbuta

Congullio

$K=2$
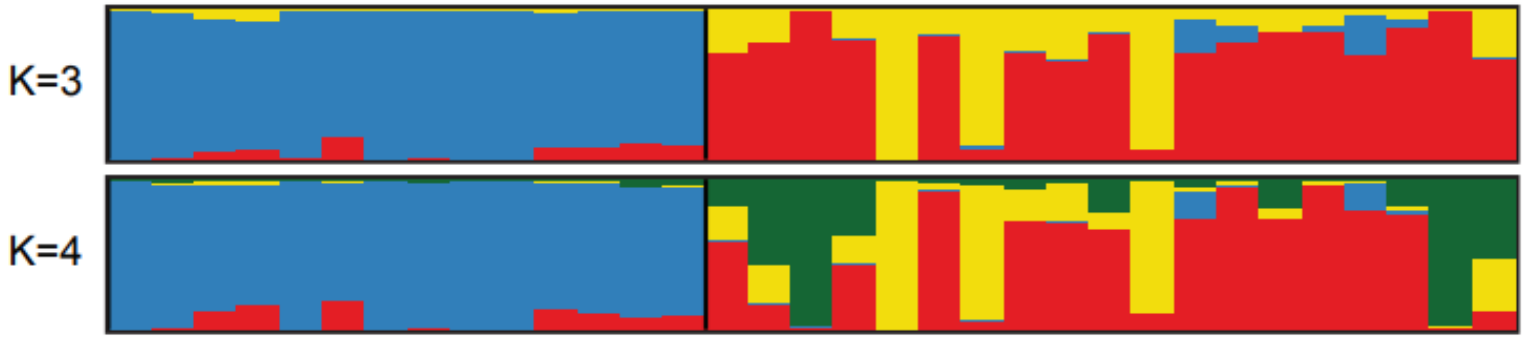

$\mathrm{K}=5$

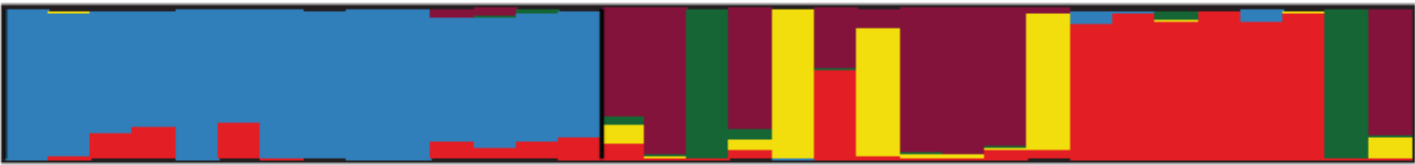

B

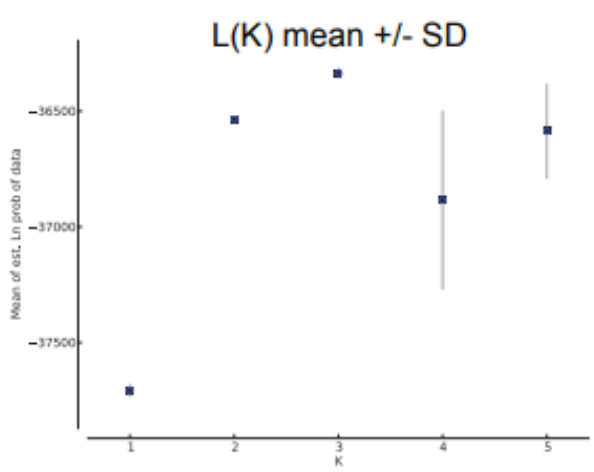

C

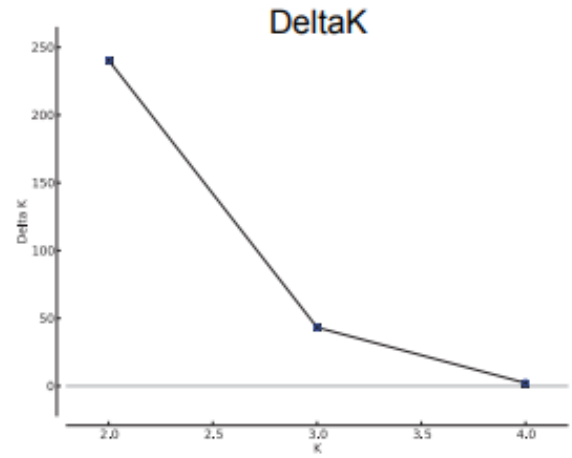




\section{Appendix 3.}

Figure A3. fineRADstructure plot showing higher levels of co-ancestry between individuals within each population than between individuals from different populations.

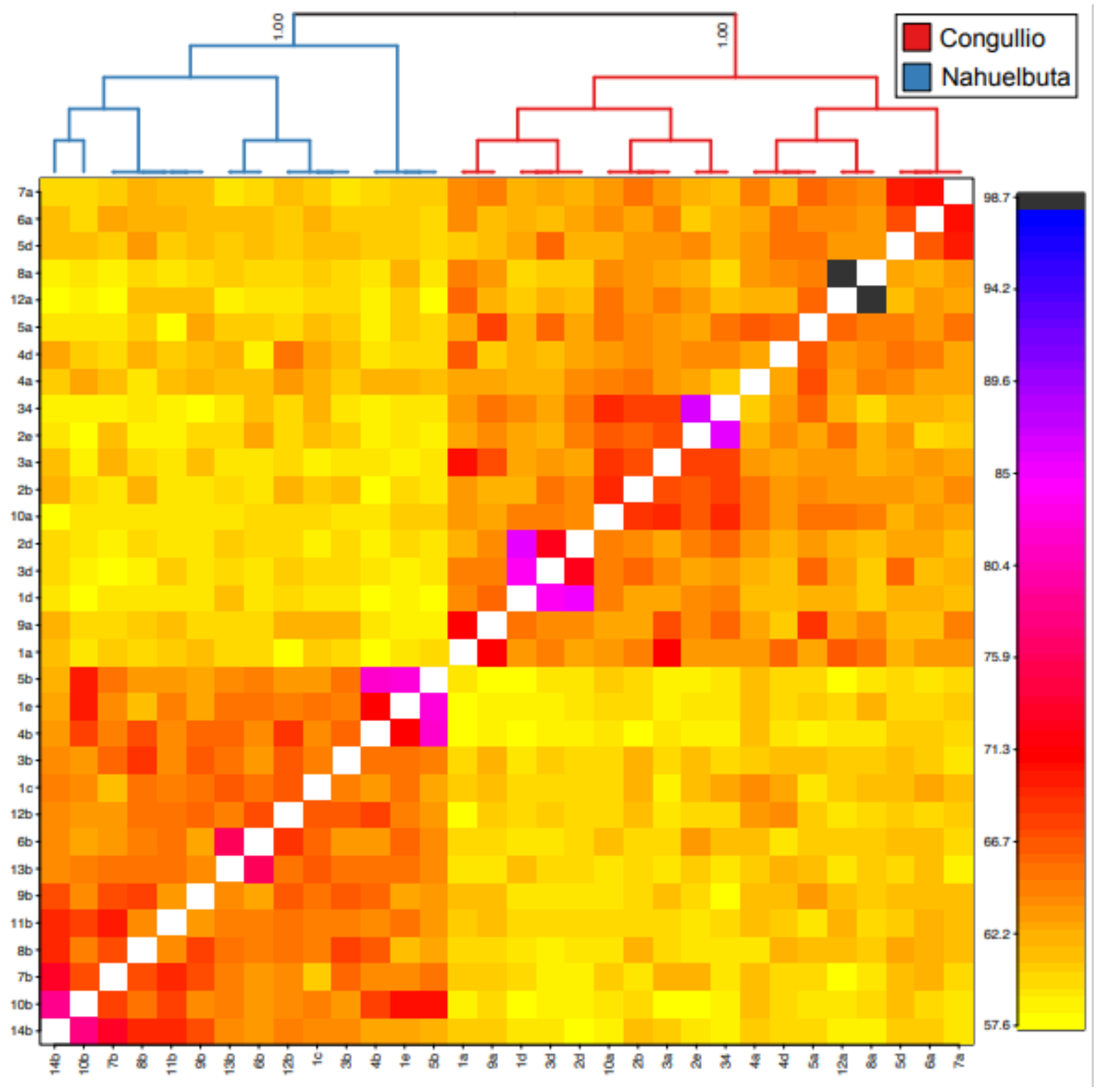

